\title{
Work in London, love in Paris: middle class mobility over the Channel Tunnel
}

\author{
Christine Barwick $^{\mathrm{a}}$ and Patrick Le Galès ${ }^{\mathrm{b}}$ \\ ${ }^{a}$ Centre Marc Bloch e.V. Berlin, Germany; ${ }^{b}$ Sciences Po, Paris, Centre d'Etudes Européennes et de \\ Politique Comparée/Sciences Po Urban School Paris, France
}

In : Journal of Ethnic and Migration Studies, 2021, Vol. 47, $n^{\circ} .17,4023-4039$

DOI : 10.1080/1369183X.2020.1763787

\begin{abstract}
Our paper contributes to the analysis of the transformation of middle classes in Europe by linking the issue of spatialization of class at the transnational and urban levels with the question of mobility and skilled migration. We therefore analyse the migration motives and urban practices (lifestyle and residential choice) of about ninety mobile middle class French nationals in London and middle class British nationals in Paris. The respondents belong to various fragments of an emerging European transnational middle class, whose diversity is reflected in their reasons for moving and their experience in the new city. Drawing on the concept of elective belonging, we argue that both the transnational and urban levels are important for class making mechanisms. Our results illustrate the relevance of the transnational level, i.e. cross-border mobility, for the making and reproduction of middle-class status. At the same time, the urban level - both the city and neighbourhood - is a crucial element that facilitates or obstructs middle-class practices, e.g. related to lifestyle or residential choice. For our respondents, multicultural London presents the economic capital of Europe with abundant professional opportunities, while Paris is viewed as a provincial city, liked for its beauty and lifestyle, but economically far behind London.
\end{abstract}

\section{KEYWORDS}

Cross-border mobility; skilled migration; European middle classes; residential choice; elective belonging

\section{Introduction}

International mobility and migration, as well as the changing scale of social structures and organisations in Europe, have caused an ongoing debate about the relation between social and spatial mobility and the making of a transnational middle class. An increasing number of studies on the mobilities of the 'ordinary' middle classes (Scott 2019) have indicated two major trends. First, different fragments of the middle class move for variegated reasons, e.g. professional, social and/or cultural (Benson 2014; Favell 2008; Ryan and Mulholland 2014; Scott 2019). These motives influence their experiences, but also the costs of cross-border mobility. Second, mobility is highly spatialised, expressed through locational decisions regarding cities and neighbourhoods, as illustrated by the importance of global cities such as New York, London or Paris, which are highly attractive for middle class migrants (Butler and Robson 2003; Favell and Recchi 2009). 
Being transnationally mobile and moving to other cities/countries is important for class making and reproduction, as it leads to the accumulation of existing resources and networks, or, in Bourdieu's terms, economic, cultural, and social capital (Bourdieu 1986), and the acquisition of new ones (transnational mobility, professional experience, language, cf. Gerhards and Hans 2013; Moret 2018; Scott and Cartledge 2009). These mobilities thus facilitate the emergence of a transnational middle class, which engages in similar mobility patterns, locational decisions, and urban practices (Andreotti, Le Galès, and Moreno Fuentes 2013). Class making mechanisms are therefore increasingly less triggered within the frontiers of the nation state, particularly in the European Union (EU) with its freedom of movement, but take place on both the transnational and local levels.

Our paper contributes to the analysis of the transformation of middle classes by linking the issue of spatialization of class at the transnational and urban levels with the question of mobility and skilled migration. We analyse the mobility between Paris and London, two prosperous world cities with strong internal inequalities attracting large waves of skilled and unskilled migrants. In contrast to most papers about migration in London, our research is not about migration from the periphery of Europe (Datta 2009; Ryan et al. 2008) or just about the crisis (King et al. 2016), but about a broad set of middle class migrants, that moved to the two cities for economic, social and/or cultural reasons. We analyse the accounts of our respondents according to two major themes: migration motivations, and lifestyle and residential choice.

The paper clearly illustrates the importance of both the transnational and urban levels for the making and reproduction of middle-classes. While the respondents moved to the two cities for a variety of reasons, including professional and social reasons, the experi-

ences in the two cities clearly differ. London is viewed by the French as the professional centre of Europe, valued also for its multicultural and open spirit. Paris, in contrast, is appreciated for its history, beauty and lifestyle, but professional opportunities are missing. Our comparative analysis thus confirms the relevance of the urban level for an emerging transnational European middle class.

\section{Theoretical framework: mobility, class, and place}

\section{Cross-border mobility and the making of a European transnational middle class}

The degree of cross-border interactions between individuals has increased quite significantly in the last decades, particularly in Europe with its Freedom of Movement. While most research focuses on the two poles of the spectrum of mobile people, i.e. migrants with a low socioeconomic background and the highly skilled, an increasing number of works have looked at the mobilities of the 'middling group', such as nurses, young entrepreneurs, university students or second generation migrants (Smith and Favell 2006; Scott 2019). As Glick-Schiller and Çağlar (2009), who called for a comparative theory of locality in migration studies, have pointed out, such skilled migrants are needed for the constitution of a globally competitive city.

Cross-border mobility is thus no longer a phenomenon exclusive to the economic elite, but to the middle classes in general. Members of the different fragments of the middle class engage in cross-border mobility for economic, social and/or cultural reasons. To illustrate, 
university graduates move to another country during or after their studies (King et al. 2016; Van Mol 2014), highly skilled migrants move to Eurocities such as London or Paris (Beaverstock 2005; Favell 2008; Ryan and Mulholland 2013; Scott 2006), and retirees with a privileged status move to France or Spain for a better quality of life, in rural areas or on the seaside (Benson 2014; Benson and O'Reilly 2016; King, Warnes, and Williams 1998). For some middle classes, spatial mobility is connected to social mobility (Scott 2019), for instance when women face obstacles for promotion in their home country (Andreotti, Le Galès, and Moreno Fuentes 2015). Those middle class members who relocate due to professional reasons usually aim to increase their professional experience.

Following the rise in cross-border mobility and the relation between spatial and social mobility, several attempts have been made to identify class making mechanisms at the European scale. Importantly, mobility in itself is a dimension of social inequality as the younger ones, better qualified and higher-earners are more mobile than other members of society (Favell and Guiraudon 2011; Mau 2010; Recchi 2015).

Andreotti, Le Galès, and Moreno Fuentes (2015) provide good evidence of a European social group of managers in the making, based on their values, urban location, choice for their children's education, labour market trajectories, and limited transnationalization. Their study of upper middle class mobile managers in four European cities (Paris, Lyon, Milan, Madrid) was a critique of the sociology of mobility (e.g. Elliott and Urry 2010) that identified disconnection processes between mobile upper middle classes and the rest of society (cf. Favell 2008). The results stressed the dominant logic of 'partial exit', indicating that European urban upper middle classes move to a foreign city, but not too far, not for too long, and they tend to come back to where they lived before. They thus practice 'transnationalism under shelter'. This confirms previous findings on the geographic and social concentration of cross-border interactions, which are rarely truly global in character (Mau, Mewes, and Zimmermann 2008).

Our study builds on and advances these works, by shedding light on the reasons for migration and its relations to class, for different fragments of the middle class. We do not focus on only lifestyle migrants or only economic migrants. These strict differen-tiations are not very useful, since, as $\operatorname{Scott}(2019,12)$ pointed out, 'economic explanations may well have more or less power for some, while sociocultural explanations may well have more or less power for others'.

\section{The spatiality of class: urban practices and belonging}

Defining middle classes is a difficult task for sociologists as they are historically defined and make sense within their national context (Zunz, Schoppa, and Hiwatari 2002). In Europe, historically, they were rooted in cities and key components of Weber's Occidental city. Urban bourgeoisies were also crucial in the making of the industrial cities of the nineteenth century, for instance in Britain (Briggs 1993). Different types of middle classes developed as part of the rise of the nation state, public policies and bureaucracies. If the state is becoming disconnected from the nation and networks are not contained within the border of the state, one would expect middle classes to adapt to the changing scale. Both transnational migrations and metropolises should become central in the making of contemporary middle classes (Le Galès 2014). In that sense, class making is likely to be more urban and transnational, beyond the national society. 
Comparing middle classes is therefore a precise endeavour (cf. Andreotti et al. 2015, chapter 1). Within the European context, middle classes are the result of several processes: The transformation of capitalism (from the industrial revolution to the rise of financialization and high tech firms), the development of the State, the inheritance of old learned professions, the development of education. We define middle classes more as social group than a class in a classic sense, in terms of employment relations, residential choices, shared norms and representations, education, wealth, income, and status, social networks and patterns of social interactions, and political mobilisation (Bagnasco 2016; Diez-Medrano 2011; Savage 2000).

As Favell and Guiraudon (2011) have argued about Europe, conceptualising class beyond the nation state has become crucial in sociology in relation to mobility, migrations and transnational networks, but also in relation to place, cities or regions. The most interesting research tries to link those elements, to identify class making mechanisms taking into account transnational dynamics and rootedness in particular places (Andreotti, Le Galès, and Moreno Fuentes 2015; Diez-Medrano et al. 2014; Mau 2010; Savage, Bagnall, and Longhurst 2005). To illustrate, Mike Savage, following earlier works by urban sociologists Ray Pahl or Herbert Gans, identified what he called the 'missing spatial dimension' of class analysis in the UK. Following Bourdieu's (1991) claim that people seek to reflect their social status in residential space, Savage, Bagnall, and Longhurst (2005) introduced the notion of elective belonging, to articulate the dynamics of globalisation, mobility and territorialisation. They build upon a tradition in sociology (Bagnasco and Negri 1994; Goldthorpe et al. 1969) that emphasised the spatial dimension of class identity formation. Elective belonging strategies play a very important role in the process of 'social location' for social classes, something quite significant in a context in which the cultural implications of occupational class have greatly eroded for most groups.

For (upper) middle classes, their status results from both their occupation and their residential choice or trajectory. Middle classes define who they are partly by the place they choose to live in (neighbourhood, city, urban region). Thus, 'middle-class residential choice is inherently spatial and social; concerns over residential environment are central to the decision over where to live' (Bacque et al. 2015, 77). Thereby, the neighbourhood plays a crucial role, as it is among the most important identifier of a person (Savage, Bagnall, and Longhurst 2005). This is confirmed by various studies, ranging from European managers (Andreotti, Le Galès, and Moreno Fuentes 2015) to middle-class Turkish-Germans in Berlin (Barwick 2016), who are all highly rooted in their neighbourhood. Just as inter-national mobility, residential choice is influenced by various factors, including family, pro-fessional, economic and social considerations. For Paris and

London, Bacque et al. (2015) have identified secluded neighbourhoods and gentrified areas as two main neighbourhood types for middle class households.

Our study advances the cited works in two ways: first, while most studies on the spatial dimension of class have been based on the mobile middle classes in the home country/city, we examine how mobile middle class members negotiate spatial belonging in their new place of residence. Moreover, our study compares place-making in two cities, London and Paris, shedding light on the relation between class and place in two different con-nected urban contexts.

We are following Savage in the hypothesis that the differentiation of spaces for interaction opens the field of the possible for individuals, in terms of belonging and of 
negotiating their involvement in a given space. Individuals are to some extent able to choose or negotiate their belonging to one political or social space or another, and their degree of investment and interaction. Reframing this issue within our argument, this means that the higher degree of freedom in choosing where to live, to shop, or to send one's children to school, in playing life at different scales, makes 'exit' or 'partial exit' strategies easier in the different dimensions of leisure, work, sociability or children's education.

\section{Comparing Paris and London}

Comparing French citizens in London to British citizens in Paris can potentially yield interesting results, considering claims that European migrants tend to move to a country that is close to their home country and that they mostly migrate for limited periods of time (Andreotti, Le Galès, and Moreno Fuentes 2015; Smith and Favell 2006). France and Britain are neighbouring countries and going with the Eurostar from Paris to London or reverse takes less than two and a half hours. Moreover, both cities have various airports and are well-connected to the rest of the respective country.

Nevertheless, despite the geographical proximity of the countries and cities, migrants, whether skilled or not, still have to face challenges, such as being in a country where people speak a different language, have a different culture, they have to find a place to live, work in a new environment, and make new friends. ${ }^{1}$ Moving always comes at a cost, disproportio-nately higher for poor migrants, but which should not be ignored for the others either (Favell 2008; Ryan and Mulholland 2013).

Our study has two advantages, which will advance the current literature on the topic. First, both samples include a variety of middle class migrants, ranging from young postgraduate students to highly-skilled bankers. We are thus not focusing on either economic, family or lifestyle migration, but examine how those factors play out for different middle class migrants. Analysing migration motivations, we will see that for the French respondents in London, professional considerations are more important for their locational decision, while many British respondents moved to Paris due to social reasons, specifically for love.

Second, our focus on two Eurocities allows us to examine the relevance of place for locational decisions and for social mobility/the accumulation of capital, which eventually facilitates the making of a transnational middle class. We specifically examine the reproduction of class through housing and lifestyle. Housing is a major dimension of inequality and where one lives and in what kind of building is major reflection of class status and membership. Both Paris and London are 'superstar cities' (Le Galès and Pierson 2019) whose high attractiveness for international migrants is mirrored in a very tight housing market, which constrains residential choice (Bacque et al. 2015). We will demonstrate that it is easier for the French in London to keep their French middle class life(style) than for the British in Paris. These latter are often not satisfied with their professional and residential status, but stay for family reasons and accept that they might have much better professional opportunities elsewhere, particularly in London.

We should add here that our interviews took place before the Brexit referendum and the endless negotiations about a withdrawal agreement. It is thus more than likely that the accounts of our respondents would be rather different now, depending on the security of their status. The presented results should thus be read keeping in mind that Brexit was not on the agenda yet. 


\section{Data and methods}

The research for this paper is in part a follow up to the series of research just mentioned and in particular Favell's book 'Eurostars in Eurocities' (2008). The idea was to use some parts of Favell's questions to look more precisely at French nationals in London and British nationals in Paris. For the research, we used the same questionnaire as Andreotti, Le Galès, and Moreno Fuentes (2015). The paper is based on semi-structured interviews with 52 French nationals in London and 37 interviews with British nationals in Paris that were conducted in 2014 and 2015. We used convenience sampling, making sure that our respondents included different fragments of the middle class, a certain age rage and different family statuses. The respondents were primarily contacted through organisations (churches, schools, bookshops, expatriate organisations, companies), and groups on social media such as Facebook and meetup. The French in London were contacted through, for example, a meetup group for French entrepreneurs in London, the French school in South Kensington, and the Facebook group 'French in London'. For the British in Paris, we also referred to Facebook groups such as English-speaking expats in Paris, or a group for English-speaking mothers. In both cities, we also went to shops that were 'typical' French or British, such as a French-bakery chain in London or a few British pubs in Paris. Lastly, we also used snowball sampling, asking the respondents for further contacts.

The interviews were semi-structured, including open-ended questions about the motives for migration, advantages and disadvantages of living in the respective city, residential choice and neighbourhood use. We also systematically assessed the respondents' spatial practices and personal networks.

The respondents were skilled migrants, middle or upper middle class, working in different occupations (for an overview of all respondents, please refer to the online supplement). Our sample is thus not about the elites or about a particular sector like the peculiar financial sector (see Ryan and Mulholland 2013). Almost all respondents had a university degree and were employed. Among the few exceptions without a higher education degree were those who left their home country after high school, but who plan to start studying.

Most respondents were married or in a partnership, whereby the share was slightly higher for the British in Paris (73\%) than for the French in London (63\%). Nineteen British respondents had children, but only thirteen had children in the same household. Among the French respondents, 26 had children and most of them (22) in the same house-hold. For the latter group, there was a gender balance among the respondents, whereas for the British, two thirds of the respondents were female. The youngest respondent was a 21-year old French woman who was working in a café in South Kensington. The eldest respondent was a 70-year old British retiree who called herself a 'travelling wife'. Most respondents, though, were between 30 and 55, mostly working fulltime, employed or self-employed. Most respondents were not first-time movers. Whether as students for an Erasmus year, after graduating to travel and work, as bankers, freelancers, or language teachers, our respondents have previously lived in places as diverse as New York, Tokyo, Australia, Berlin, Costa Rica, Haiti, or the Middle East, and have hence acquired a lot of experience, resources and networks.

We need to point out one caveat with our sample. While we included in both cases different fragments of the middle class, the differences we found may still be partly due 
to our sampling method. In France, we contacted many respondents through organisations and institutions that catered to the French community, so that the embeddedness in French social circles might result from the sampling. In Paris, we had more difficulty finding respon-dents and it is possible that those who are highly satisfied are also more 'invisible'.

\section{Eurocities London and Paris}

Studying French nationals in London and British nationals in Paris presents a unique opportunity to capture transnational practices by taking 'global/international cities or regions as the unit of comparison into which immigrants integrate' (Favell 2015, 106). London and Paris are the two major urban escalator regions in Europe (Fielding 1992), comprising between eleven and twelve million inhabitants, i.e. about twenty per cent of the population, producing nearly a third of the GDP. Within the national and European (and party global) space, London and Paris accumulate the high end of the labour market, skilled people (the young in particular) and investment. This wealth is associated with economic activity (often concentrated in finance, services, technologies), the attraction of flows and sometimes a search for safe havens among global economic elites.

According to Favell $(2008,30)$, (pre Brexit) London appeared in the 2000s as the 'brightest beacon in Europe's landscape. For those in search of fame and fortune'. After decades of demographic decline (between 1939 and 1991 London lost 2.2 million inhabitants, about 25 per cent) the population of London increased by two million over the last 25 years. Latest projections (before Brexit) anticipated continuous growth up to eleven million in 2050. More than forty per cent are black or have an ethnic minority background. The symbolic dimension of 'experiencing London' became a distinctive characteristic for young people and middle classes alike. Objective factors supported London's attraction, e.g. an opened labour market and London's economic boom during the 2000s, a growth reinforced by massive immigration. Foreigners were easily able to step in, from young people who could not enter their own labour markets, eastern European workers, to middle classes or bankers in the city of London. British Universities transformed and attracted scores foreign students from all over the word, including Europeans eager to get an experience outside their own national systems.

Paris shares some common features with London as a long established capital of a centralised country, where most of its elites are trained in the Grandes écoles. Paris is a sort of escalator region for young people from all over the country, where those who 'survive' have improved opportunities for upward mobility in comparison with the rest of the country. Those who move in have a good chance to find high-paying jobs, to build human capital, and to access social and cultural resources that enhance the prospects for passing their improved social prospects on to their children. Within France, Paris is most diverse in terms of ethnicity and nationalities, a magnet attracting and the same time rejecting people, from France and abroad, an urban region of around twelve million inhabitants, with good transportation links to the rest of France, Europe and the world. The centralisation of the labour market has increased as the economy was restructured under the command of the State. Both Paris and London are the regions where upper middle classes have concentrated and developed over time (Préteceille 1995).

We therefore compare the French in London and British in Paris, as two contrasting cases of transnational urban elective belonging. 


\section{Results}

\section{Migration motivations to cross the Channel}

British in Paris: romantic Francophiles 'stuck in Paris' because of their partner

Among our British respondents most had been to France before and already had some familiarity with the country, due to school exchanges, holidays, or other visit that gave them the opportunity to speak or learn the language.

As is always the case, a number of British respondents moved to Paris because of employment opportunities. Some have come to work for international organisations: law firms, banks, OECD, consultants. A classic case is that of Tyler, a sales director working for a British firm that opened a branch in Paris. He speaks French and was offered a job in the new branch. The same applies to Kevin, a business investment advisor who was transferred by his employer to Paris. Another group we interviewed came to teach English in Paris, either institutionally, e.g. at the British Council, business schools, universities, or companies, or privately. From there, several moved on to other jobs.

The main finding emerging from our interviews is that most of our respondents did not move to Paris for professional, but for love reasons. A third of the British respondents moved to Paris to live with their partner and can be considered 'mixed-nationality relationship migrants'. They had previously met their partner (in France, the UK or a third country) and came to Paris to live as a couple, whether they spoke French or not. ${ }^{2}$

To illustrate, Lucie, 33, a freelance fashion writer, initially came to Paris to join her husband. She had 'nothing else to do', had learned French before and 'wanted to finish what I started' during her Erasmus in France, and so she moved to Paris. Amanda, 26 years old, even came to France without knowing the language. She and her partner first lived in the South of France with his family who taught her French, before moving on to Paris. Shaun, Ethan and Laura have similar stories. They were all married to a French person, had children, and moved to Paris to be closer to the spouses' families. These cases confirm previous findings that 'the presence of children did tend to draw mixednationality relationship migrants back home' (Scott and Cartledge 2009, 77). This move 'back home' turned our respondents into migrants in Paris. We did not expect the cliché of romantic Paris to appear so bluntly in our interviews, but it did, par-ticularly for the younger ones. Joining a love partner was one of the major reasons for our British respondents to move to Paris.

However, while the move to Paris facilitated relationships, it often impeded professional opportunities, in particular for those with limited French. Most respondents were very critical about the French labour market and their professional status. They complained about the weak economy, the tax system, and the business culture in general. Laura, owner and founder of a recruitment agency, makes a point that was shared by various other respondents as well: 'France is not particularly well at the moment, economi-cally it's very harsh, Parisians always look for the bad. I also find the French administration extremely heavy, to the point of ... you know, it's really quite tiresome'.

Several of our interviewees who came to Paris to follow their partner/spouse and went for good jobs (finance, video games) have also become critical because of the obstacles of moving to other jobs. To illustrate, Kevin worked at a bank when he came to Paris in 2000. At the time of the interview, he was employed as a Business Investment Adviser and 
complained that professional opportunities were much worse than before. He considered himself 'stuck' in Paris due to his family - his wife had a job she could not perform in England. For business reasons, he would have long returned to London. Just as Kevin, other British respondents also thought that there were more job and business opportunities in London, in particular for people like them.

Thus, the British respondents saw their work position as second rate. Their professional situation is comparable to that of Italian migrants who moved to Paris after the economic crisis and suffered from a 'poor association between educational credentials and current occupations' (Dubucs et al. 2016, 8). In contrast to Italians, however, the British respon-dents felt that they might have better job opportunities in their home country. They rated London highly and had a sense of being away from the real economic capital of Europe, where it would be easier to acquire more economic, cultural and social capital. Partners and family ties were the main reason they did not move to London or another economic centre but accepted their 'second rate' position in Paris.

\section{French in London: work, aspirations, doing business}

The story is quite different for our French middle class respondents in London. In comparative terms and in accordance with the accounts of officials we interviewed in London, economic reasons play a much more important role for the migration decision of the

French than the British respondents. A classic first set of interviewees was well identified: they were in London because of Inter Company Transfers (ICTs) and/or with expatriate contracts ${ }^{3}$, which was much more common than UK staff sent to Paris. They were mostly male professionals who went to London with their family. Another important group in the sample were those men and women who have decided to go to London to open their own business, working in domains such as fashion, real estate, wine marketing, graphics and IT. Their discourse about London reflects classic narratives about the UK and London admin-istration compared to the French one, as providing a much more favourable context for entrepreneurs. This echoes a classic argument among French business elites and newspa-pers. More precisely, the respondents argued that the legal regulations around opening one's own business are much more relaxed in the UK than in France. Taxes are lower than in France, and only deduced from actual profit, which creates a business culture that allows for trial and error. The business culture thus seems to be much more open in the UK. Marie, 36 years, freelance female legal advisor explained: 'Taxes make it easier to open one's firm .... I I have to be honest, I don't stay [in London] for this but that's why I do not come back to France'. Thomas, 34 years old and entrepreneur in the web industry, pointed to one of the main differences between being an entrepreneur in the UK versus in France, in a classic statement about the right wing representation of the two cities:

Success is viewed as a strength in the UK, compared to Paris where it is not so good to be successful. (...) People get jealous and as an entrepreneur people think that you are basically having slaves working for you.

For the French respondents, in the banking sector just as for young entrepreneurs, London is the place to be. The openness for business is also related to ethnic origin, a point forcefully put forward by Huc-Hepher and Drake (2017) within their sample. For Madi, 28 years, the only French respondent with North-African origin in our sample, 
being in London was seen as a liberating experience as he is not viewed as the 'Arab'. Madi has been in London for 15 years and opened his own restaurant in South Kensington, close to the French school. He has grown up in a Paris banlieue (working class suburban high rise estate) and learned early in school that children like him will not make it far in life.

That was too much. Because in France (...) I come from the banlieue, they made us believe that succeeding means making 800 Euros. They wanted to teach us that we should be happy with only little. But if you come here [London], if you want to make a million, you can make a million.

Compared to the British in France, love did not appear as a major reason for moving to London. Some respondents, primarily women, followed their partner/husband, but there was not one respondent who joined their British partner in London. However, for many respondents, culture and lifestyle appeared as relevant factors for moving to London, particularly after the studies. Various respondents had the choice between different cities, within and outside Europe, but opted for London due to the positive image they had of the city. Greta, the youngest one in the sample (21 years) worked in a café in South Kensington and came to London to fulfil her dream of experiencing 'the big city'. Thus, while London is mostly attractive due to its economic opportunities, its cultural offers and image as multicultural city clearly add to its attraction.

Overall, our French middle class respondents in London expressed a strong sense of satisfaction: they were succeeding in the economic capital of Europe, worked with excellent professionals from all over the world. They also conveyed a sense of superiority vis-àvis French middle classes. In terms of class boundaries (Lamont and Duvoux 2014), they felt part of the economically successful class of professionals in London.

The migration decisions thus illustrate that, while both samples include different fragments of the middle class, overall, professional reasons were systematically more important for the locational decisions of the French who moved to London. For the British respondents, love reasons were more relevant, meaning and they often had to compromise regarding their professional status.

We will now turn to the analysis of class reproduction through lifestyle and housing. We basically find a continuity of the accounts, with a higher satisfaction among the French in London compared to the British in Paris.

\section{Lifestyle and residential choice: enjoying the French life in Paris ... and in London}

In general, the French respondents were highly satisfied with their life in London. They characterised London as a multicultural and highly diverse city, they found people to be very open and tolerant, and thought that Londoners have a certain mind-set that involves that people do not take themselves too seriously. The professional opportunities were highly valued, just as the abundant cultural offers. They also expressed a sense of being culturally 'valued' (in the sense of Lamont) in London.

Even though the French respondents highly rated London, many continued to be embedded in French social circles. This was particularly obvious for those who came to London as ICTs with their family and settled close to a French school, such as in South Kensington. Walking around in that neighbourhood, one hears primarily French, e.g. 
when ordering a coffee, in the French bookstore, or the French institute with its many cultural events. Even those French respondents, mostly younger ones and usually without children, who drew a clear boundary towards 'those in South Kensington', often still socialised in French circles. A reason for that might be a certain incomprehension of and cultural distance towards the British pub culture. While some respondents bemoaned the difficulty of making British friends, they also acknowledged that it might be their own fault as they found the pub culture rather superfluous and preferred to invite friends over for dinner. These, then, were mostly French friends. Moving in social circles with people from the same nationality (who at the same time share the experience of migration) underscores previous findings concerning the difficulty and costs associated with forming/ extending one's network in a new city/country (Ryan and Mulholland 2014).

The British respondents in Paris had a slightly different narrative: one the one hand, they very much enjoyed and appreciated what they perceived as the 'French lifestyle', which in fact is quite common for middle classes in many countries: buying food in the food market, dining out, having a coffee in one of the many cafes, seeing friends and family and sharing a glass of wine, strolling around in the streets and parks. This lifestyle appeared more relevant in Paris because of the urban form. They liked that Paris is made up of many small neighbourhoods, which provides a 'neighbourhood feeling'. Never short of mobilising clichés about the city, many English respondents thought that Montmartre the neighbourhood made famous through the film Amélie Poulain - was the neighbourhood with the most authentic Paris feeling.

On the other hand, they perceived Paris as more provincial than London. While this was not necessarily seen as a disadvantage, Paris had less the feeling of an open and multicultural world city, which was reflected in the attitudes of the Parisians, as viewed by the British respondents. They complained about the locals for one particular reason: they felt that the Parisians had no respect, admiration, or esteem for them. In terms of prestige, they made the point that the English in Paris were not well considered. The most negative factor about Paris was therefore the Parisians, who were described as rude, negative, aggressive. Asked about the disadvantages of living in Paris, 'the Parisians' became a standard answer. To illustrate, Nathalie, who has been in Paris since 2010, stated that 'people are the hardest thing'. Even for the 'mixed nationality relationship migrants', who should have an advantage establishing a local network (cf. Scott and Cartledge 2009), this was perceived as very difficult. Moreover, it seemed to limit their sense of feeling at home, i.e. a more limited elective belonging.

Comparing the respondents' satisfaction with their social life and lifestyle, we can summarise that the French in London felt part of a transnational (upper) middle class that fit well to the open and cosmopolitan city of London. In contrast, the British in Paris felt less appreciated. They perceived Paris more like a provincial than a world- or Euro-city.

In both cities, the housing market is very tight, and rent per square metre is among the highest in Europe, which clearly limits housing and neighbourhood choice. Two things are different in Paris and London: first, there is no single neighbourhood with a considerable share of British nationals. British pubs and bookshops are scattered around the city. Even in the Western suburbs around the British School of Paris of Croissy sur Seine deep into the upper middle class territory, there is rather an English-speaking or expat than a British community. Second, finding an apartment is more of a challenge in Paris as a potential renter needs to present many more documents than in London, including an employment 
contract, the last three salary slips, and a French guarantor, who has to be either a home owner or have a salary that is at least three times the rent. For newcomers in France, it is usually very hard to come up with all these documents. They thus face difficulties in the housing market and take the first apartment that they can get with limited choice of the neighbourhood.

Freddie, 55 and English teacher, came to Paris as a student. At that time, he found a 'chambre de bonne', a small room under the roof, also called shoebox room. Due to the tight housing market, he has been living there since. He was planning to finally buy his own apartment in Paris and move out of the shoebox room. Joseph faced a different problem. After his divorce, he needed to find an apartment with an extra bedroom for when his daughter would visit him, according to the court-ruling. A two-bedroom apartment for a single person is expensive, as in most dynamic cities. His choice was thus strongly constrained and he characterised his neighbourhood in the Northern part of Paris 'loud, noisy, polluted'.

For those who already knew someone in Paris or joined their partner in the city, these already existing social networks proved to be crucial in finding an apartment. Here again, however, the idea was to find an apartment at all, not to find an apartment in a particular neighbourhood. This is a classic result about Paris (Andreotti, Le Galès, and Moreno Fuentes 2015). Many foreigners and Parisians alike see Paris as Paris city council, i.e. the dense core with all the services and metro. For many of them, with differences of course, the key point is to live 'intra muros', i.e. within the city itself (cf. Dubucs et al. 2016). They want to avoid a couple of neighbourhoods or have preferences for some of them but what is essential is to live 'dans Paris' and not in the suburbs ${ }^{4}$. So the choice of neighbourhood was seen as less crucial and often our interviewees declared they were ready to live in any other one. For many respondents, their middle class status was thus not reflected in the neighbourhood or housing choice, except that they lived in the inner-city.

Exceptions were those upper middle class respondents living in the bourgeois 16th arrondissement or the Western suburbs, close to the British School of Paris. While their residential choice was constrained in that it was primarily based on the educational environment, the residence in the affluent parts of Paris mirrored their class status. Thus, despite its location outside the inner ring, the British respondents who lived around the British school still saw their place of living as positive. They said that it was quiet, had many green spaces, and was still close enough to the centre of Paris. Moreover, in clear contrast to Paris intra-muros, the area around the school is characterised by detached family homes, not small and crowded apartment buildings.

By contrast in London where the inner core is less distinctive, even though the rent prices are even higher than in Paris, most respondents chose their neighbourhood very precisely and are thus a good illustration of 'elective belonging'. To rent an apartment in London, only the rent and security deposit are required. The younger ones within the sample and those without children mostly lived in trendy gentrified inner-city neighbourhoods such as Islington or Brixton. They valued these districts' centrality, the availability of cafes, bars and shops. Some others chose to move to the outer boroughs of London, the 'commuter belt', trading space for distance.

For the French in London who chose the neighbourhood based on its educational infrastructure, quite a few saw the high share of other French residents rather critical. Felix, 30 
years, lived in Clapham with his wife and three children, close to a bi-lingual school. He was very fond of his neighbourhood but did not like that there were so many French residents. Suzie said the same about South Kensington. She was one of the three 'trailing spouses' (wives) in our sample. She used to work as a nurse, but stopped working to move with her husband and three children to London. While she liked South Kensington, she also viewed the high number of French co-residents as a disadvantage. For the other two interviewed 'trailing spouses', living in close proximity to other French nationals and a well-developed French 'infrastructure' was perceived as a clear advantage, particularly for meeting new people and building a local network (cf. Ryan and Mulholland 2014).

Overall then, living in a neighbourhood with a high share of co-nationals was seen both positively and negatively. While the French respondents knew well that it may impede contact to the natives, living in a French community provided them with a feeling of home, away from home. This community feeling and the educational security also made up for the high rent prices particularly in South Kensington.

\section{Discussion}

In this paper, we analysed the migration motives, satisfaction with lifestyle and residential choice, comparing and contrasting mobile middle class French nationals in London and middle class British nationals in Paris, as a way to think about different components of elective belonging put forward by Savage and colleagues (2005). The respondents in both samples belong to various fragments of an emerging European transnational middle class, including young graduates, entrepreneurs and highly skilled in the banking or related sector. The motivations for moving to the respective city reflected this diversity, ranging from economic reasons for the (upper) middle classes living in London's South Kensington or Paris' West, to cultural and social reasons for the younger ones, often without children, who primarily lived in the inner-cities, often in gen-trified neighbourhoods. Despite the limitation of our sample, if the French overwhel-mingly go to London to work, the main reason for the British to come to Paris appeared to be love.

Scott and Cartledge (2009) mention King (2002:, 99-100), who ident-ified the rising importance of 'love migration': 'whilst the accelerating speeds and technol-ogies of travel and communication in a shrinking Europe increase the chance of such transnational love being maintained'. He urges researchers to 'not underestimate the libi-dinal factor in migration', an urge that is clearly reinforced by the results of our study.

We argue that the urban context is an important element of class making mechanisms.

Our French respondents seem rather satisfied with their life in London for two reasons: they live what they see as the French lifestyle, they have the feeling that the rest of the population in London rates them as a prestigious group associated with good food, culture and all the clichés related to the French. By choosing London, they go beyond the boundaries of French middle classes. Even low middle class respondents see themselves as

part of a more transna-tional European or cosmopolitan middle class, differentiating themselves, i.e. valuing them-selves in comparison to the French middle class. In that sense, transnational mobility and elective belonging in London triggered a sense of belonging to a transnational middle class without giving up profound roots in the French culture and way of life.

Things are different in Paris. Though also a Eurocity and escalator region it might support, and is valued for, a middle class lifestyle, but offers fewer opportunities for 
professional advancement for the English. The British respondents resent the lack of esteem from the Parisians, as well as their residential and work situation. Their elective belonging is less complete, leading to mixed feelings about the place they chose including serious negative points. In that sense, their belonging is as much constrained as chosen.

Both the reasons for migration as well as the narrative about life in the two cities are very stereotypical, with little distance. The French see London as the economic capital of Europe with abundant professional opportunities, as a multicultural city where every-one can live in one's own community, and where the French are well considered. Paris is viewed by the English as a rather provincial city, valued mostly for its history, beauty and the way of life, but is economically far behind London. These stereotypical depictions also contribute to understanding the importance of the urban scale for the making of a transnational middle class. In both cases, our respondents clearly see themselves in relation to the local middle class, with games of distance and proximity contributing to different mechanisms of class making in the two cities.

The results also confirm previous criticism on the idea of a free-floating transnational (upper) middle class. Particularly the case of the British in France demonstrates that mobi-lity can come with major costs, not only economically, but also emotionally. Moving abroad does not always add to one's resources or capital, particularly if the labour market situation changes due to an economic crisis. Moreover, if the development of a feeling of home is obstructed, mobility is not necessarily seen as positive.

We want to stress again that even though we found different predominating (not exclusive!) migration motivations for the two samples, we cannot be sure about the extent to which they reflect the actual make up of middle class migrants in the two cities. Whether or not 'love' migrants are more prevalent in Paris and 'economic' migrants more prevalent in London would need to be confirmed by a larger study. What we can confirm with our data is that both cities attract a variety of middle class migrants, and that their experiences are structured not only by their migration motivations, but also the city they live in.

Finally, we want to get back to Brexit. For the British in Paris, Brexit is a disaster and it will likely make their life more difficult. To being able to stay in Paris/France, they need to apply for a residence permit or citizenship, a process that is not accessible for everyone (Benson 2019). For the French in London, Brexit is an utter disaster that has broken their representation and their self-esteem. Maybe, despite the London (remain-) vote, parts of British society do not see them with the positive attributes they imagined, but actually resent them. Something of an ideal dream world has been broken by the Brexit vote and the never ending disastrous negotiations.

\section{Notes}

1. Not to mention Brexit - a topic for the next step of the research.

2. As part of the research, we tried to measure themes on twitter conversations between London and Paris, done by Matthieu Jacomy at the Medialab of Sciences Po. Although our exploration was not very successful, the most common subject for tweets linking individuals in Paris and London was personal relationships and love

3. We are working on a data base to document business exchanges between Paris and London, including in the world on banking or when a transnational firm (for instance Microsoft) organize its European activities in Europe between several European cities including 
London or Paris. Large service firms with offices in Paris and London will send staff in the other place for instance

4. According to ongoing research, this is probably changing as many young middle classes families have increased the long term trend of leaving to the immediate surroundings of Paris, hence the difference between Paris and next door suburbs is in decline for the new generation, also as the metro lines are now reaching those communes.

\section{Funding}

This work was supported by Paris City Council, Programme Paris 2030 (CONVENTION n²012 DDEEES 218 'Paris Londres 2030').

\section{References}

Andreotti, A., P. Le Galès, and J. Moreno Fuentes. 2013. “Transnational Mobility and Rootedness: the Upper Middle Classes in European Cities." Global Networks 13 (1): 41-59.

Andreotti, A., P. Le Galès, and J. Moreno Fuentes. 2015. Globalised Minds, Roots in the City, Upper Middle Classes in European Cities. Oxford: Wiley-Blackwell.

Bacque, M. H., G. Bridge, M. Benson, et al. 2015. The Middle Classes and the City: A Study of Paris and London. New York, NY: Palgrave Macmillan.

Bagnasco, A. 2016. La questione del ceto medio. Bologne: Il Mulino.

Bagnasco, A., and N. Negri. 1994. Classi, Ceti, Persone. Esercizi Di Analisi Sociale Localizzata. Naples: Liguori.

Barwick, C. 2016. Social Mobility and Neighbourhood Choice: Turkish-Germans in Berlin. London/ New York: Routledge.

Beaverstock, J. V. 2005. "Transnational Elites in the City: British Highly-Skilled Inter-Company Transferees in New York City's Financial District." Journal of Ethnic and Migration Studies 31 (2):

245-268.

Benson, M. 2014. "Trajectories of Middle-Class Belonging: The Dynamics of Place Attachment and Classed Identities." Urban Studies 51 (14): 3097-3112.

Benson, M. 2019. "Brexit and the Classed Politics of Bordering: The British in France and European

Belongings." Sociology. published online first: https://doi.org/10.1177/0038038519885300. Benson, M., and K. O'Reilly. 2016. "From Lifestyle Migration to Lifestyle in Migration: Categories, Concepts and Ways of Thinking." Migration Studies 4 (1): 20-37.

Bourdieu, P. 1986. “The Forms of Capital." In Handbook of Theory and Research for the Sociology of Edcuation, edited by J. Richardson, 241-258. New York: Greenwood.

Bourdieu, P. 1991. "Physischer, Sozialer und Angeeigneter Physischer Raum." In Stadt-Räume, edited by M. Wentz, 25-34. Frankfurt am Main: Campus.

Briggs, A. 1993. Victorian Cities. Vol. 2. Berkeley/Los Angeles: University of California Press.

Butler, T., and G. Robson. 2003. "Negotiating Their way in: The Middle Classes, Gentrification and the Deployment of Capital in a Globalising Metropolis." Urban Studies 40 (9): 1791-1809.

Datta, A. 2009. "Places of Everyday Cosmopolitanisms: East European Construction Workers in London." Environment and Planning A 41 (2): 353-370. 
Diez-Medrano, J. 2011. "Social Class and Identity." In Sociology of the European Union, edited by A. Favell and V. Guiraudon, 28-49. London: Palgrave McMillan.

Diez-Medrano, J., C. Cortina, A. Safranoff, and T. Castro-Martín. 2014. "Euromarriages in Spain:

Recent Trends and Patterns in the Context of European Integration." Population, Space and Place 20 (2): 157-176.

Dubucs, H., T. Pfirsch, E. Recchi, and C. Schmoll. 2016. “Je Suis un Italien de Paris: Italian Migrants' Incorporation in a European Capital City." Journal of Ethnic and Migration Studies 43 (2): 578-595.

Elliott, A., and J. Urry. 2010. Mobile Lives. Abingdon, UK: Routledge.

Favell, A. 2008. Eurostars and Eurocities. Malden, MA: John Wiley \& Sons.

Favell, A. 2015. Immigration, Integration and Mobility: New Agendas in Migration Studies. Colchester: ECPR Press.

Favell, A., and V. Guiraudon. 2011. Sociology of the European Union. Basingstoke: Palgrave Macmillan.

Favell, A., and E. Recchi. 2009. Pioneers of European Integration: Citizenship and Mobility in the EU. Cheltenham, UK; Northampton, MA: Edward Elgar Pub.

Fielding, A. J. 1992. "Migration and Social Mobility: South East England as an Escalator Region." Regional Studies 26 (1): 1-15.

Gerhards, J., and S. Hans. 2013. "Transnational Human Capital, Education, and Social Inequality. Analyses of International Student Exchange.” Zeitschrift für Soziologie 42 (2): 99-117.

Glick-Schiller, N., and A. Çağlar. 2009. "Towards a Comparative Theory of Locality in Migration Studies: Migrant Incorporation and City Scale.” Journal of Ethnic and Migration Studies 35 (2): 177-202.

Goldthorpe, J. H., D. Lockwood, F. Bechhofer, and J. Platt. 1969. The Affluent Worker in the Class Structure. London/New York: Cambridge University Press.

Huc-Hepher, S., and H. Drake. 2017. "From the 16ème to South Ken? A Study of the Contemporary French Population in London." In A History of the French in London: Liberty, Equality, Opportunity, edited by D. Kelly and M. Cornick, 391-429. London: Humanities Digital Library.

King, R. 2002. "Towards a New Map of European Migration." International Journal of Population Geography 8 (2): 89-106.

King, R., A. Lulle, F. Conti, and D. Mueller. 2016. "Eurocity London: A Qualitative Comparison of Highly Skilled Migrants in London.” Global Networks 14 (2): 148-166.

Graduate Migration from Germany, Italy and Latvia.” Comparative Migration Studies 4 (3): 1-22.

King, R., A. M. Warnes, and A. M. Williams. 1998. "International Retirement Migration in Europe." International Journal of Population Geography 4 (2): 91-111.

Lamont, M., and N. Duvoux. 2014. "How Neo-Liberalism has Transformed France Symbolic Boundaries?” French Politics, Culture and Society 32 (2): 57-75.

Le Galès, P. 2014. "States in Europe, Uncaging Societies and the Limits to Infrastructural Power." Socio Economic Review 12 (1): 1-22.

Le Galès, P., and P. Pierson. 2019. "'Superstar Cities' \& the Generation of Durable Inequality." Daedalus 148 (3): 46-72.

Mau, S. 2010. Social Transnationalism: Lifeworlds Beyond The Nation-State. Abingdon, UK: Routledge.

Mau, S., J. Mewes, and A. Zimmermann. 2008. "Cosmopolitan Attitudes through Transnational Social Practices?” Global Networks 8 (1): 1-24.

Moret, J. 2018. European Somalis' Post-Migration Movements: Mobility Capital and the Transnationalisation of Resources. Cham, Switzerland: Springer.

Préteceille, E. 1995. "Division sociale de l'espace et globalisation. Le cas de la métropole parisienne." Sociétés Contemporaines 22 (1): 33-67.

Recchi, E. 2015. Mobile Europe. The Theory and Practice of Free Movement in the EU. London: Palgrave Macmillan.

Ryan, L., and J. Mulholland. 2013. “Trading Places: French Highly Skilled Migrants Negotiating Mobility and Emplacement In London." Journal of Ethnic and Migration Studies 40 (4): 584-600. Ryan, L., and J. Mulholland. 2014. "French Connections: The Networking Strategies of French 
Ryan, L., R. Sales, M. Tilki, and B. Siara. 2008. "Social Networks, Social Support and Social Capital: The Experiences of Recent Polish Migrants in London.” Sociology 42 (4): 672-690.

Savage, M. 2000. Class Analysis and Social Transformation. London: Open University Press.

Savage, M., G. Bagnall, and B. Longhurst. 2005. Globalization and Belonging. London: Sage. Scott, Sam. 2006. "The Social Morphology of Skilled Migration: The Case of the British Middle Class in Paris." Journal of Ethnic and Migration Studies 32 (7): 1105-1129.

Scott, S. 2019. "New Middle-Class Labor Migrants." In The Palgrave Handbook of Ethnicity, edited by S. Ratuva, 1-20. Singapore: Palgrave Macmillan.

Scott, S., and K. H. Cartledge. 2009. "Migrant Assimilation in Europe: A Transnational Family Affair." International Migration Review 43 (1): 60-89.

Smith, M. P., and A. Favell. 2006. The Human Face of Global Mobility: International Highly Skilled Migration In Europe, North America And The Asia-Pacific. New Brunswick/London: Transaction Publishers.

Van Mol, C. 2014. Intra-European Student Mobility in International Higher Education Circuits. London: Palgrave Macmillan UK.

Zunz, O., L. Schoppa, and N. Hiwatari, eds. 2002. Social Contracts Under Stress. The Middle Classes of America, Europe and Japan at the Turn of the Century. New York: Russell Sage. 